\title{
PRELIMINARY EVALUATION OF 29 OLIVE (Olea europaea L.) CULTIVARS FOR PRODUCTION AND ALTERNATE BEARING, IN THE HUASCO VALLEY, NORTHERN CHILE
}

\author{
Francisco Tapia C. ${ }^{1 *}$, Freddy Mora $^{2}$, and Alexandra I. Santos ${ }^{3}$
}

\begin{abstract}
There is increasing interest in the development of intensively managed olive orchards (Olea europaea L.) in northern Chile. The selection of specific varieties that perform well on a particular site is considered crucial to maximizing productivity. The present study was undertaken to evaluate the productive performance of 29 varieties of olive in the Huasco Valley $\left(28^{\circ} 34^{\prime} \mathrm{S}, 70^{\circ} 47^{\prime} \mathrm{W}\right)$, Northern Chile. The traits evaluated were: mean olive production per tree considering a longitudinal (PML) analysis over a period of five years, 2003 to 2007, total olive production in the same period (PA03-07) and alternate bearing index (ABI). The effect of variety was highly significant $(\mathrm{p}<0.01)$ for all traits. In the field trial, IAP was moderate (0.52), with PML $37.7 \mathrm{~kg}^{-1} \mathrm{ree}^{-1}$ and PA-0307 $186 \mathrm{~kg}$ tree $\mathrm{e}^{-1}$. Spearman correlation coefficients between rankings of each trait were positive and significantly different from zero $(\mathrm{p}<0.05)$. 'Leccino' performed best based on fruit production alone. 'Arbequina', 'Picholine', 'Manzanilla Racimo', 'Picual', 'Manzanilla de Sevilla', 'Frantoio' and 'Ascolana Huasco' evidenced both high productivity and the lowest alternate bearing. These cultivars could be recommended in Huasco if a farmer is seeking to recover establishment costs rapidly, but we emphasize that a longer-term longitudinal study should be carried out before large-scale deployment.
\end{abstract}

Key words: Olea europaea, olive fruit, alternate bearing.

\section{INTRODUCTION}

The olive is among the oldest cultivated trees in the world. Currently, olive cultivation is associated with several countries of the Mediterranean Sea basin and plays an important role in the diets, economies and cultures of the region (Zamora et al., 2001). Olive cultivation, however, has extended beyond this region to South America, South Africa and Australia. The olive is considered a dry climate crop, capable of sustaining long periods of water deficit (Angelopoulos et al., 1996; Selles et al., 2006) and with a moderate tolerance to saline soils (Benlloch et al., 1991; Isidoro and Aragüés, 2006), because of which it has been successfully cultivated in saline soils where other fruit trees cannot grow.

${ }^{1}$ Instituto de Investigaciones Agropecuarias INIA, Centro Experimental Huasco, Casilla 149, Vallenar, Chile. *Corresponding author(fatapiac@inia.cl).

${ }^{2}$ Universidad de Concepción, Facultad de Ciencias Forestales, Casilla 160-C, Concepción, Chile.

${ }^{3}$ Universidade Estadual de Maringá, Centro de Ciências Agrárias, Avenida Colombo 5790 Bloco 05, CEP: 87020-900. Maringá, Paraná, Brasil.

Received: 26 November 2007.

Accepted: 09 April 2008.
Olive cultivation forms part of the Chilean fruit production with exports to 26 countries (Tapia and Escobar, 2007). There are different regions of the country that are suitable for olive. Huasco Valley, located in the southern part of the Atacama Desert, is considered an appropriate region for olive production on a large scale (Mora et al., 2008a). The quality of the oil produced in this region, along with acceptable levels of productivity, has generated interest among agricultural producers and agro-industrial investors.

Owing to the importance that olive production is beginning to assume in the regional agricultural context, the Instituto de Investigaciones Agropecuarias (INIA) has undertaken several research and development program with the species (Astorga and Mora, 2005; Selles et al., 2006; Tapia et al., 2006) to meet the technological needs of producers. Among the strategies for productive improvement of olive orchards in the region is the evaluation/selection of varieties that respond better to the environmental growing conditions.

In the context of new olive orchards, agricultural producers in this region are interested in developing varieties (or using already existing ones) that in addition 
to producing a high quality oil, present aspects such as early production (with the objective of obtaining a rapid return on investment), minimal alternate production and high fruit production per tree, among other characteristics (Mora et al., 2007; 2008a; 2008b).

The present study had the objective of evaluating the productive behavior of 29 olive varieties in the Huasco Valley, in function of average fruit production per tree, in a longitudinal analysis over a period of 5 years (2003 a 2007), accumulated production over the same period and the alternate bearing index.

\section{MATERIALS AND METHODS}

The research was carried out at the INIA's Huasco Experimental Station located at Vallenar (28 ${ }^{\circ} 34^{\prime}$ S, 70 $47^{\circ}$ ' W), Atacama Region, Chile.

Twenty-nine olive varieties were used, drawn from the INIA Germplasm Bank, located in Huasco Region, Atacama Region in northern Chile. The varieties were: Arbequina, Arbusana, Ascolana Huasco, Ascolana Tenera, Barnea, Biancolilla, Bossana, Carrasqueña Huasco, Oliva di Cerignola, Coratina, Empeltre, Frantoio, Grappolo Limarí, Itrana, Kalamata, Koroneiki, Leccino, Liguria, Manzanilla Chilena, Manzanilla Racimo, Manzanilla de Sevilla, Nabali, Nocellara del Belice, Nociara, Novo, Picholine, Picual, Picuda and Sevillano. The number of trees per variety used in the analysis ranged from five to seven. The plants came from clonal propagation through nebulization of semi-woody cuttings.

A single pruning for conduction was carried out at planting, which consisted of eliminating secondary twigs of less than $80 \mathrm{~cm}$, leaving anything over this threshold to grow freely.

The trees were planted in the year 2000 at a distance of $7 \times 7 \mathrm{~m}$ in a thin carbonate calcareous soil with loamy to loam clayey texture belonging to Aridisol order (CICAHidroconsult, 1980). A drip irrigation method was used, arranged in simple rows with drippers spaced at $1 \mathrm{~m}$ and a flow of $3.8 \mathrm{~L} \mathrm{~h}^{-1}$. The annual volume of water was on average $8000 \mathrm{~m}^{3} \mathrm{ha}^{-1}$.

The climate, as defined by Novoa et al. (1989), is a typology termed subtropical marine desert, Copiapó agroclimate, characterized by an annual average temperature of $18{ }^{\circ} \mathrm{C}$, mean maximum of $30.1{ }^{\circ} \mathrm{C}$ (February) and mean minimum of $6.5^{\circ} \mathrm{C}$ (July).

The olive varieties and their replications were distributed randomly in an area of $10000 \mathrm{~m}^{2}$, the experimental unit being a tree. Management after planting was free growth without pruning. Fertilization was based on nitrogen in dosages of $60 \mathrm{U} N$ per year. Disease control was based on two preventive and curative applications of copper to control leaf spot (Spilocaea oleagina (Castagne) Hughes).

\section{Evaluations}

Fruit production for individual trees was measured for a period of 5 consecutive years from 2003 to 2007 (PML, $\mathrm{kg}$ tree $\left.^{-1}\right)$. Subsequently, accumulated production was estimated for the period 2003-2004 (PA03-07, kg tree-1) and the alternate bearing index (ABI) was calculated using the following formula (Pearce and DobersekUrbanc, 1967):

$A B I=\left(\frac{1}{(n-1)}\right)\left\{\frac{\left|\left(a_{2}-a_{1}\right)\right|}{a_{1}+a_{2}}+\frac{\left|\left(a_{3}-a_{2}\right)\right|}{a_{2}+a_{3}}+\frac{\left|\left(a_{4}-a_{3}\right)\right|}{a_{3}+a_{4}}+\frac{\left|\left(a_{5}-a_{4}\right)\right|}{a_{4}+a_{5}}\right\}$

where $n$ is the number of years of evaluation; $a_{1}, a_{2}, a_{3}, a_{4}$ and $a_{5}$ are fruit production per tree for a determined year (2003 a 2007).

\section{Statistical analysis}

A longitudinal analysis was carried out for the PML variable. The prior assumptions of normality were analyzed using the Shapiro and Wilk (1965), and chisquared normality tests. In the absence of normality, the longitudinal analysis was conducted using the methodology of generalized estimation equations (GEE), an extension of the generalized linear models (GLM) for correlated data (Myers et al., 2002). Data distribution graphs were constructed using SAS-INSIGHT and the UNIVARIATE procedure of SAS (SAS Institute, 1996). The GEE longitudinal analysis was carried out using the GENMOD procedure (SAS Institute, 1996). Comparison of the correlation structures of the working correlation matrix (WCM) was done according to Liang and Zeger (1986) and Myers et al. (2002).

For the analysis of PA03-07 and ABI, the SAS MIXED procedure (SAS Institute, 1996) was used with the restricted maximum likelihood (REML) method (Patterson and Thompson, 1971) to calculate residual variance and adjust the model (Mora and Scapim, 2007). Spearman correlation coefficients were calculated, including bootstrap confidence intervals $(95 \%)$ between the characteristics under study, in accordance with Efron (1979).

\section{RESULTS AND DISCUSSION}

Table 1 presents the results of the statistical significance analysis for the agronomic characteristics under evaluation: PML, PA03-07 and ABI. The effect owing to variety was highly significant $(\mathrm{p}<0.01)$ in the three characteristics. The average ABI was moderate $(0.52)$, which can be 
explained by the juvenile state of the trees. Longitudinal mean production was $37.37 \mathrm{~kg}^{\mathrm{k}} \mathrm{tre}^{-1}$ and accumulated production of $186 \mathrm{~kg}_{\text {tree }}{ }^{-1}$. In accordance with León et al. (2004) the description of variability observed in the olive genotypes in diverse agronomic characteristics, which include productivity per tree, estimation of environmental variability and variability over time (year to year), are fundamental to improve the efficiency of improvement programs or the introduction of new olive varieties. The differences found in this study among the varieties indicate a favorable situation for the selection of cultivars for northern Chile and further indicate that the strategy of selecting varieties is proving effective from the point of view of improving productivity.

Table 2 shows the results of the GEE analysis carried out for the average fruit production characteristics for the period 2003 to 2007. Liang and Zeger (1986) proposed the GEE methodology as an application of quasi-likelihood (Wedderburn, 1974) to adjust a GLM to clustered data (as in longitudinal analysis). The GEE are considered an extension of the GLM. In practical terms, GEE is useful when there are repeated measurements of the same experimental units and the variable response is not adjusted to a normal distribution. In the present study, the Shapiro-Wilk and chi-squared tests showed the absence of a normal distribution. Graphic analysis reveals the presence of an asymmetric distribution, which in this case was considered Gamma, in accordance with Freund (1992) and Myers et al. (2002). WCM showed a correlation among clusters (agricultural periods) of less than 0.3 , indicating that an independence structure matrix would be the most appropriate for adjusting the model (Liang and Zeger, 1986; Myers et al., 2002).

The cultivars Arbequina, Ascolana Huasco, Barnea, Carrasqueña Huasco, Coratina, Empeltre, Frantoio, Grappolo Limarí, Koroneiki, Leccino, Manzanilla Racimo, Manzanilla de Sevilla, Nabali, Novo, Picholine, Picual, and Picuda had a positive effect on mean production of the assay, indicating that these varieties would maximize production under the conditions under which the study was conducted. 'Oliva di Cerignola' and 'Itrana' had the lowest performances, which significantly lowered the mean production of the assay. Based on the mean production of the period analyzed, these two cultivars should not be included in the productive improvement program if early producing varieties are desired. The variety with the best yield was 'Leccino' (estimated weight $0.9151 ; \mathrm{p}<0.01$; Table 2), but this yield was not significantly different from those of 'Picholine' (0.9062), 'Picuda' (0.8988), 'Arbequina' (0.8661) and 'Picual' $(0.8417)$ (Table 3$)$. On the other hand, the varieties that did not present a significant response $(\mathrm{p}>0.05)$ according to the GEE (Table 2), such as 'Biancolilla', did not have any influence (positive or negative) on mean production.

Although 'Leccino' presented a higher response to both average and accumulated production, it did not present a satisfactory ABI (Table 4) and was not classified among the 10 best varieties in terms of alternance production. Although the results are considered preliminary, owing to the juvenile state of the assay, this result should be considered in the subsequent evaluations of the assay, given that according to Levin and Lavee (2005) alternate bearing is still a serious problem in the cultivation of numerous fruit species, including olives, which consequently must be managed in order to minimize the adverse effects on production (Tapia et al., 2006). Unlike PML and PA03-07, ABI did not present significant differences among the 10 best varieties (Table 3 ).

Notably, the varieties 'Arbequina', 'Picholine', 'Manzanilla Racimo', 'Picual', 'Manzanilla de Sevilla', 'Frantoio' and 'Ascolana Huasco' have satisfactory responses in the three agronomic characteristics, which is a key aspect for multiple selections. This result is in accordance with the Spearman correlation coefficient estimated among the ranking of each characteristic (Table 4), which were positive and significant (bootstrap confidence interval, $95 \%$ probability, does not include the zero value), implying that selection for one agronomic characteristic can have positive effects on other variables of interest.

Table 1. Results of statistical significance analysis for three agronomic traits evaluated in 29 olive varieties from Valle del Huasco, northern Chile from the 2003 to 2007 growing seasons.

\begin{tabular}{|c|c|c|c|c|c|c|c|}
\hline \multirow[b]{2}{*}{ Item } & \multirow[b]{2}{*}{ DF } & \multicolumn{2}{|c|}{$\begin{array}{c}\text { PML } \\
\left(\text { kg tree }^{-1}\right)\end{array}$} & \multicolumn{2}{|c|}{$\begin{array}{l}\text { PA03-07 } \\
\left(\text { kg tree }^{-1}\right)\end{array}$} & \multicolumn{2}{|c|}{$\begin{array}{c}\mathrm{ABI} \\
\text { (scale } 0 \text { to 1) }\end{array}$} \\
\hline & & $\chi^{2}$ & $\mathbf{P}>\chi^{2}$ & Value of $F$ & $\mathbf{P}>\mathbf{F}$ & Value of $F$ & $\mathbf{P}>\mathbf{F}$ \\
\hline Effect of variety & 28 & 62.8 & 0.0002 & 5.38 & $<0.0001$ & 3.1 & $<0.0001$ \\
\hline Average & & \multicolumn{2}{|c|}{37.7} & \multicolumn{2}{|r|}{186.0} & \multicolumn{2}{|r|}{0.52} \\
\hline LV & & \multicolumn{2}{|c|}{-2889.1} & \multicolumn{2}{|r|}{-575.8} & \multicolumn{2}{|r|}{19.2} \\
\hline Method of analysi & & \multicolumn{2}{|c|}{ GENMOD-GEE } & \multicolumn{2}{|c|}{ MIXED-REML } & \multicolumn{2}{|c|}{ MIXED-REML } \\
\hline
\end{tabular}

LV: likelihood logarithm of the adjusted model; PML: average production of fruit per tree; PA03-07: accumulated production; ABI: alternate bearing index; GENMOD-GEE: procedure of Generalized Estimation Equations; MIXED-REML: procedure of Mixed Linear Models. 
Table 2. Estimates of generalized estimation equation parameters for fruit production of 29 olive varieties, evaluated in Valle del Huasco, northern Chile, by using a longitudinal study (2003 to 2007 growing seasons).

\begin{tabular}{|c|c|c|c|c|c|c|}
\hline \multirow[b]{2}{*}{ Parameter } & \multirow[b]{2}{*}{ Estimate } & \multirow[b]{2}{*}{ SE } & \multicolumn{2}{|c|}{ CI (95\%) } & \multirow[b]{2}{*}{ Z Value } & \multirow[b]{2}{*}{$\mathbf{P}>|\mathbf{Z}|$} \\
\hline & & & Low & High & & \\
\hline Intercepto & 3.2088 & 0.104 & 3.0051 & 3.4126 & 30.87 & $<0.0001$ \\
\hline Arbequina & 0.8661 & 0.1503 & 0.5715 & 1.1606 & 5.76 & $<0.0001$ \\
\hline Arbusana & -0.055 & 0.2569 & -0.5585 & 0.4485 & -0.21 & 0.8304 \\
\hline Ascolana Huasco & 0.5664 & 0.2047 & 0.1651 & 0.9676 & 2.77 & 0.0057 \\
\hline Ascolana Tenera & -0.0223 & 0.1251 & -0.2674 & 0.2229 & -0.18 & 0.8587 \\
\hline Barnea & 0.4038 & 0.1764 & 0.058 & 0.7496 & 2.29 & 0.0221 \\
\hline Biancolilla & 0.1585 & 0.1353 & -0.1068 & 0.4237 & 1.17 & 0.2417 \\
\hline Bossana & -0.314 & 0.3409 & -0.9821 & 0.354 & -0.92 & 0.3569 \\
\hline Carrasqueña Huasco & 0.7116 & 0.1587 & 0.4006 & 1.0226 & 4.48 & $<0.0001$ \\
\hline Cerignola & -0.5258 & 0.1042 & -0.73 & -0.3215 & -5.04 & $<0.0001$ \\
\hline Coratina & 0.5465 & 0.2007 & 0.1532 & 0.9398 & 2.72 & 0.0065 \\
\hline Empeltre & 0.5287 & 0.1374 & 0.2595 & 0.798 & 3.85 & 0.0001 \\
\hline Frantoio & 0.7581 & 0.11 & 0.5424 & 0.9737 & 6.89 & $<0.0001$ \\
\hline Grappolo & 0.5102 & 0.1493 & 0.2175 & 0.8029 & 3.42 & 0.0006 \\
\hline Itrana & -1.4918 & 0.17 & -1.8249 & -1.1587 & -8.78 & $<0.0001$ \\
\hline Kalamata & 0.2725 & 0.1835 & -0.0872 & 0.6323 & 1.48 & 0.1376 \\
\hline Koroneiki & 0.3486 & 0.1679 & 0.0196 & 0.6776 & 2.08 & 0.0378 \\
\hline Leccino & 0.9151 & 0.1082 & 0.7029 & 1.1272 & 8.45 & $<0.0001$ \\
\hline Liguria & 0.2688 & 0.1615 & -0.0478 & 0.5855 & 1.66 & 0.0961 \\
\hline Manzanilla Chilena & 0.1605 & 0.2078 & -0.2468 & 0.5679 & 0.77 & 0.4399 \\
\hline Manzanilla Racimo & 0.7697 & 0.1077 & 0.5587 & 0.9808 & 7.15 & $<0.0001$ \\
\hline Manzanilla de Sevilla & 0.5991 & 0.1291 & 0.3461 & 0.8521 & 4.64 & $<0.0001$ \\
\hline Nabali & 0.4436 & 0.1323 & 0.1843 & 0.7028 & 3.35 & 0.0008 \\
\hline Nocellara del Belice & 0.0878 & 0.1497 & -0.2056 & 0.3811 & 0.59 & 0.5577 \\
\hline Nociara & -0.0455 & 0.1716 & -0.3819 & 0.2908 & -0.27 & 0.7907 \\
\hline Novo & 0.4284 & 0.1404 & 0.1533 & 0.7035 & 3.05 & 0.0023 \\
\hline Picholine & 0.9062 & 0.3038 & 0.3107 & 1.5017 & 2.98 & 0.0029 \\
\hline Picual & 0.8417 & 0.3474 & 0.1608 & 1.5226 & 2.42 & 0.0154 \\
\hline Picuda & 0.8988 & 0.1659 & 0.5736 & 1.2239 & 5.42 & $<0.0001$ \\
\hline Sevillano & 0 & 0 & 0 & 0 & - & $\cdot$ \\
\hline Correlation & $\varrho=0$ (independent $)$ & & & & & \\
\hline
\end{tabular}

SE: standard error; $\mathrm{CI}$ : confidence interval; $\mathrm{Z}$ : Z value of normal standardized distribution; P: probability.

\section{CONCLUSIONS}

While the data presented are preliminary, the varieties Arbequina, Picholine and Picual should receive special attention owing to their high productive capacity and an adequate alternate bearing index in the first 5 years of production in the Huasco Valley.

'Leccino' stood out for its higher productive response, while 'Arbequina', 'Picholine', 'Manzanilla Racimo',
'Picual', 'Manzanilla de Sevilla', 'Frantoio' and 'Ascolana Huasco' presented high production with a low alternate bearing index. These cultivars can be recommended in Huasco if an agricultural producer is seeking to rapidly recover the costs of establishing, with minimal alternate bearing, although it is suggested that there be a long term study for the development of orchards on a large scale. 
Table 3. Best 10 varieties based on mean production, from longitudinal analysis considering the 2003 to 2007 growing seasons (PML), accumulated production (PA03-07) and alternate bearing index (ABI) evaluated in Valle del Huasco, northern Chile.

\begin{tabular}{|c|c|c|c|c|c|}
\hline \multicolumn{2}{|c|}{$\begin{array}{c}\text { PML } \\
\left(\mathrm{kg} \mathrm{tree}^{-1}\right)\end{array}$} & \multicolumn{2}{|l|}{$\begin{array}{l}\text { PA03-07 } \\
\left(\text { kg tree }^{-1}\right)\end{array}$} & \multicolumn{2}{|c|}{$\begin{array}{c}\text { ABI } \\
\text { (scale } 0 \text { to 1) }\end{array}$} \\
\hline Variety & Average & Variety & Average & Variety & Average \\
\hline Leccino & $61.8 \mathrm{a}$ & Leccino & $306.5 \mathrm{a}$ & Arbequina & $0.28 \mathrm{a}$ \\
\hline Picholine & $61.3 \mathrm{ab}$ & Picholine & $303.8 \mathrm{ab}$ & Picholine & $0.35 \mathrm{a}$ \\
\hline Picuda & $60.8 \mathrm{ab}$ & Picuda & $301.5 \mathrm{ab}$ & Manzanilla Racimo & $0.36 \mathrm{a}$ \\
\hline Arbequina & $58.8 \mathrm{ab}$ & Arbequina & $291.7 \mathrm{ab}$ & Picual & $0.38 \mathrm{a}$ \\
\hline Picual & $57.4 \mathrm{ab}$ & Picual & $284.6 \mathrm{ab}$ & Manzanilla de Sevilla & $0.39 \mathrm{a}$ \\
\hline Manzanilla Racimo & $53.4 \mathrm{~b}$ & Manzanilla Racimo & $264.7 \mathrm{ab}$ & Frantoio & $0.40 \mathrm{a}$ \\
\hline Frantoio & $52.8 b$ & Frantoio & $261.6 a b$ & Grappolo & $0.41 \mathrm{a}$ \\
\hline Carrasqueña Huasco & $50.4 \mathrm{bc}$ & Carrasqueña Huasco & $249.6 \mathrm{ab}$ & Ascolana Huasco & $0.41 \mathrm{a}$ \\
\hline Manzanilla de Sevilla & $45.1 \mathrm{c}$ & Manzanilla de Sevilla & $222.8 b$ & Nocellara del Belice & $0.43 \mathrm{a}$ \\
\hline Ascolana Huasco & $43.6 \mathrm{c}$ & Ascolana Huasco & $215.5 b$ & Ascolana Tenera & $0.44 \mathrm{a}$ \\
\hline Average & 54.6 & & 270.2 & & 0.38 \\
\hline
\end{tabular}

Values in columns followed by different letters indicate significant differences $(\mathrm{p}<0.01)$ according to orthogonal contrasts. ABI scale, 0 : no alternance exists, 1 : alternance is complete.

Table 4. Spearman correlation coefficients (and bootstrap confidence intervals, 95\%, between parentheses) between traits for 29 olive varieties evaluated in Valle del Huasco, northern Chile.

\begin{tabular}{lccc}
\hline Characteristic & PML & PA03-07 & ABI \\
\hline PML & 1.000 & $0.937(0.918-0.957)$ & $0.607(0.265-0.948)$ \\
PA03-07 & & 1.000 & $0.526(0.184-0.868)$ \\
ABI & & & 1.000 \\
\hline
\end{tabular}

PML: average fruit production per tree; PA03-07: accumulated production; ABI: alternate bearing index.

\section{RESUMEN}

Evaluación preliminar de la produción y añerismo en 29 variedades de olivo (Olea europaea L.) en el Valle del Huasco, Norte de Chile. En el norte de Chile existe un creciente interés en el desarrollo de huertos de olivo (Olea europaea L.) manejados intensivamente. La selección de variedades específicas que han respondido bien en un sitio en particular es considerada clave para la maximización de la productividad. El presente estudio fue realizado para evaluar el desempeño de algunas características agronómicas en 29 variedades de olivo, en el Valle del Huasco (28 34' S, $70^{\circ} 47^{\prime}$ O), norte de Chile. Las características analizadas correspondieron a producción de frutos promedio por árbol (PML) en un análisis longitudinal durante un período de 5 años, 2003 a 2007, producción acumulada del mismo período (PA0307) y el índice de alternancia de producción (ABI). El efecto debido a la variedad fue altamente significativo ( $p$
$<0,01)$ para las tres características. El ABI fue moderado (0,52), con una PML de 37,37 kg árbol ${ }^{-1}$ y PA03-07 de 186 $\mathrm{kg}$ árbol $^{-1}$. Correlaciones de Spearman entre los ranking de cada característica fueron positivas y significativamente diferentes de cero $(p<0,05)$. 'Leccino' tuvo la mejor respuesta considerando únicamente la producción de frutos. 'Arbequina', 'Picholine', 'Manzanilla Racimo', 'Picual', 'Manzanilla de Sevilla', 'Frantoio' y 'Ascolana Huasco' evidenciaron conjuntamente tanto alta productividad como baja alternancia de producción. Estos cultivares podrían ser recomendados en Huasco si un agricultor desea recuperar los costos de establecimiento rápidamente, aunque para el desarrollo de huertos a gran escala, se sugiere la realización de un estudio de largo plazo.

Palabras clave: Olea europaea, aceitunas, alternancia de producción. 


\section{LITERATURE CITED}

Angelopoulos, K., B. Dichio, and C. Xiloyannis. 1996. Inhibition of photosynthesis in olive trees (Olea europaea L.) during water stress and rewatering. J. Exp. Bot. 47:1093-1100.

Astorga, M., y F. Mora. 2005. Componentes de varianza e interacción variedad-sitio del vigor, producción y productividad de Olea europaea, en Chile. Cerne 11:25-33.

Benlloch, M., F. Arboleda, D. Barranco, and R. Fernández-Escobar. 1991. Response of young olive trees to sodium and boron excess in irrigation water. HortScience 26:867-870.

CICA-Hidroconsult. 1980. Estudio agrológico del Valle del Río Huasco. 158 p. Secretaría Regional de Planificación y Coordinación SERPLAC-Región de Atacama, Copiapó, Chile.

Efron, B. 1979. Bootstrap methods: Another look at the Jackknife. Ann. Stat. 7:1-26.

Freund, J.E. 1992. Mathematical statistics. $5^{\text {th }}$ ed. 658 p. Prentice-Hall, New Jersey, USA.

Isidoro, D., and R. Aragüés. 2006. Modeling survival of young olive trees (Olea europaea L. cv. Arbequina) in saline and waterlogging field conditions. Agron. J. 98:795-799.

León, L., L. Rallo, C. Del Río, and L.M. Martín. 2004. Variability and early selection on the seedling stage for agronomic traits in progenies from olive crosses. Plant Breed. 123:73-78.

Levin, A.G., and S. Lavee. 2005. The influence of girdling on flower type, number, inflorescence density, fruit set, and yields in three different olive cultivars (Barnea, Picual, and Souri). Aust. J. Agric. Res. 56:827-831.

Liang, K.Y., and S.L. Zeger. 1986. Longitudinal data analysis using generalized linear models. Biometrika 73:13-22.

Mora, F., y C.A. Scapim. 2007. Predicción de valores genéticos del efecto de poblaciones de maíz evaluadas en Brasil y Paraguay. Agric. Téc. (Chile) 67:139-146.

Mora, F., F. Tapia, A. Ibacache, E.N. Martins, and C.A. Scapim. 2008a. Genetic evaluation of olive clones in the Atacama desert, Chile. Agrociencia 42:777-786.

Mora, F., F. Tapia, C.A. Scapim, and E.N. Martins. 2007. Vegetative growth and early production of six olive cultivars, in southern Atacama desert, Chile. J. Cent. Eur. Agric. 8:269-276.
Mora, F., F. Tapia, C.A. Scapim, E.N. Martins, R.J.B. Pinto, and A. Ibacache. 2008b. Early performance of Olea europaea cv. Arbequina, Picual and Frantoio in the southern Atacama Desert. Crop Breed. Appl. Biotechnol. 8:30-38.

Myers, R.H., D.C. Montgomery, and G.G. Vining. 2002. Generalized linear models, with applications in engineering and the sciences. 342 p. John Wiley and Sons Press, New York, USA.

Novoa, R., S. Villaseca, P. del Canto, J. Rouanet, C. Sierra, y A. del Pozo. 1989. Mapa agroclimático de Chile. 221 p. In Novoa, R. (ed.) Instituto de Investigaciones Agropecuarias (INIA), Santiago, Chile.

Pearce, S.C., and S. Dobersek-Urbanc. 1967. The measurements of irregularity in growth and cropping. J. Hortic. Sci. 42:295-305.

Patterson, H.D., and R. Thompson. 1971. Recovery of inter-block information when block sizes are unequal. Biometrika 58:545-554.

SAS Institute. 1996. Statistical analysis system: user's guide. 956 p. SAS Institute, Cary, North Carolina, USA.

Selles, G., R. Ferreyra, I. Selles, y G. Lemus. 2006. Efecto de diferentes regímenes de riego sobre la carga frutal, tamaño de fruta y rendimiento del olivo cv. Sevillana. Agric. Téc. (Chile) 66:48-56.

Shapiro, S.S., and M.B. Wilk. 1965. An analysis of variance test for normality (complete samples). Biometrika 52:591-611.

Tapia, L.I., y H.A. Escobar. 2007. Evolución de las exportaciones de aceitunas de Chile entre los años 1993-2005. Idesia 25:17-22.

Tapia,F.,A. Ibacache, y F. Mora. 2006. Manejo del añerismo en el valle del Huasco. VII Jornadas Olivícolas - I encuentro Iberoamericano de Olivicultura, La Serena, Chile. 4, 5 y 6 de octubre. Instituto de Investigaciones Agropecuarias, La Serena, Chile.

Wedderburn, R.W.M. 1974. Quasi-likelihood functions, generalized linear models, and the Gauss-Newton method. Biometrika 61:439-447.

Zamora, R., M. Alaiz, and F.J. Hidalgo. 2001. Influence of cultivar and fruit ripening on olive (Olea europaea) fruit protein content, composition, and antioxidant activity. J. Agric. Food Chem. 49:4267-4270. 